\title{
PARTICIPATION OF LOCAL GOVERNMENT, REIGION FINANCIAL DEVELOPMENT AND ECONOMIC GROWTH: EMPIRICAL STUDY ON SOUTHWEST OF CHINA
}

\author{
Pan Linwei ${ }^{1, a}$, Wu Yaling ${ }^{2, b}$ \\ 1 School of Economic and Management, Chongqing Jiaotong University, Chongqing,China; \\ 2 School of Accounting, Chongqing University of Technology and Business, Chongqing,China \\ apanlinwei2000@sina.com, b*505147749@qq.com
}

Keywords: participation of local government, finance development, economic growth, regional deference

\begin{abstract}
Based on panel data of 4 provinces of Southwest of China during 1999-2014, this paper empirically test the relation between financial development and economic growth on the consideration of local government participation. The regression results shows there is a magnificent, positive relation between independent variables and economic growth in 4 provinces of Southwest of China. And the finance development in past decades has contributed immensely to economic growth. And there is a significant regional deference in the regression results of 4 provinces. So the promotion from finance development in Chongqing and Sichuan has more obvious, notable effect than which in Guizhou and Yunnan province. Local government need to transfer their focus of participation, not only on finance scale, but also on efficiency of financial system. The correct position of government will facilitate more the development of finance and economic growth in long run.
\end{abstract}

\section{Introduction}

Scholars are very interested in the massive forces of economic growth. There are a number of theoretical and empirical studies have explored the relationship between the deepening of finance and economic progress. Goldsmith (1969), Shaw (1973) and McKinnon (1973) have pioneering contribution and guidance to later literatures. We have noticed that government is always a leading role in the transition of centrally planned economy to market system. And government-oriented market economy has made more progress in China than expected in fact, the local governments play an even crucial and important role in the course of allocation of finance resources.

With rapid economic progress of China in past decades, the function and process of finance deepening and role of government became the research focus. In the research on the relation between finance development and government participation in Middle of China, YU Xuyou(2011) states that local governments has strong demand on regional economic growth as a result of rat race on GDP with others regions. In the process of race, government participation became the main force in finance deepening, which would be a supplementary solution to the defect of market mechanism. ZHANG Jing \& SHEN Kunrong(2008) concluded that it is necessary to integrate reform of fiscal and finance deepening, which is crucial to the transition of economic growth and enhancement of resource allocative effectiveness. It should be noted that there is a strong desire to develop more rapidly in western regions of China. LI Zeming(2012) argues the administrative intervene from local governments in west provinces has significant effect on finance development.

We do agree with the conclusions that economic growth is influenced by many factors dedicated by previous academic literatures, especially in the case of exogenous factors. Ever since there are many pioneering contributions of previous works on the topic, and provide useful insights on some of the consequences of financial development or of financial reform, they do not address directly and comprehensively the question of whether financial liberalization has resulted in a more efficient allocation of finance resource in the process of rapid economic development in China. As we all know that the development of west region of China is lower than the rest, such as Jiangsu, Zhejian 
province and others.

Under the base of 4 provinces of Sichuan, Yunan, Guizhou and Chongqing, this paper aims to examine the relationship between financial development and the role of local government for the case of Southwest of China over the period 1999-2014. Specifically, what kind of role has government played to the finance development and economic growth process? What kind of effect, positive or negative, has government exerted on finance development?

The rest of the paper is organized as follows. And Section 1 describes key variables and data resources, indicator measure and descriptive statistics in this work. Section 2 discusses the methodological issues in the panel data framework. Section 3 presents the empirical results and relevant discussions. And main conclusions would be delivered at the end of the whole paper.

\section{EMPIRICAL MODELS AND VARIABLE STATIONARITY TEST}

\subsection{Empirical Models}

We first briefly show our empirical models, discuss our data sources, variable definitions, and give some summary statistics. We then give the empirical results and also report. As well, we briefly discuss some of the measured effects of the control variables and report additional robustness checks.

Following the standard literature and improving upon the theoretical postulate of (Zhu Qin,2006; Zhao Danni et al.,2015; Lin Chun et al.,2015), we specify economic growth relationship as:

$$
G D P_{i, t}=\alpha_{i}+\beta_{1 i} \text { FIR }_{i, t}+\beta_{2 i} M I_{i, t}+\beta_{3 i} \text { Trade }_{i, t}+\gamma_{i} X_{i, t}+\mu_{i}
$$

On the consideration of eliminate the heteroscedasticity fluctuations in time series data, we take the natural logarithm of all variables in this paper. And the model can be expressed as:

$$
\ln G D P_{i, t}=\alpha_{i}+\beta_{1 i} \ln F I R_{i, t}+\beta_{2 i} \ln M I_{i, t}+\beta_{3 i} \ln \text { Trade }_{i, t}+\gamma_{i} \ln X_{i, t}+\mu_{i} \text { (2). }
$$

In the equation (1), (2) above, the dependent variable is $\ln G D P$ indicates the economic growth (excluding price factors); FIR indicates finance amount, and FIR is the ratio of balance of deposit and loan of financial institutions/GDP. MI is the market index which represents government participation in financial system. Trade is the total amount of import and export trade in region, which indicates the degree of opening to the outside world of each region. Finally, we choose the fixed assets investment and education as the control variable. The statistical analysis software is Eviews 8.0, and all data is from Statistical Yearbook of China issued by China National Bureau of Statistics (http://data.stats.gov.cn/).

\subsection{Descriptive Statistics of Data}

On the consideration of the difference of population and area in the four provinces, we compared the GDP per capital in GUIZHOU, SICHUAN,YUNNAN,CHONGQING and National level. Which variable indicate the division of economic growth between the 4 regions. The Figure 1 reports the statistical results. 


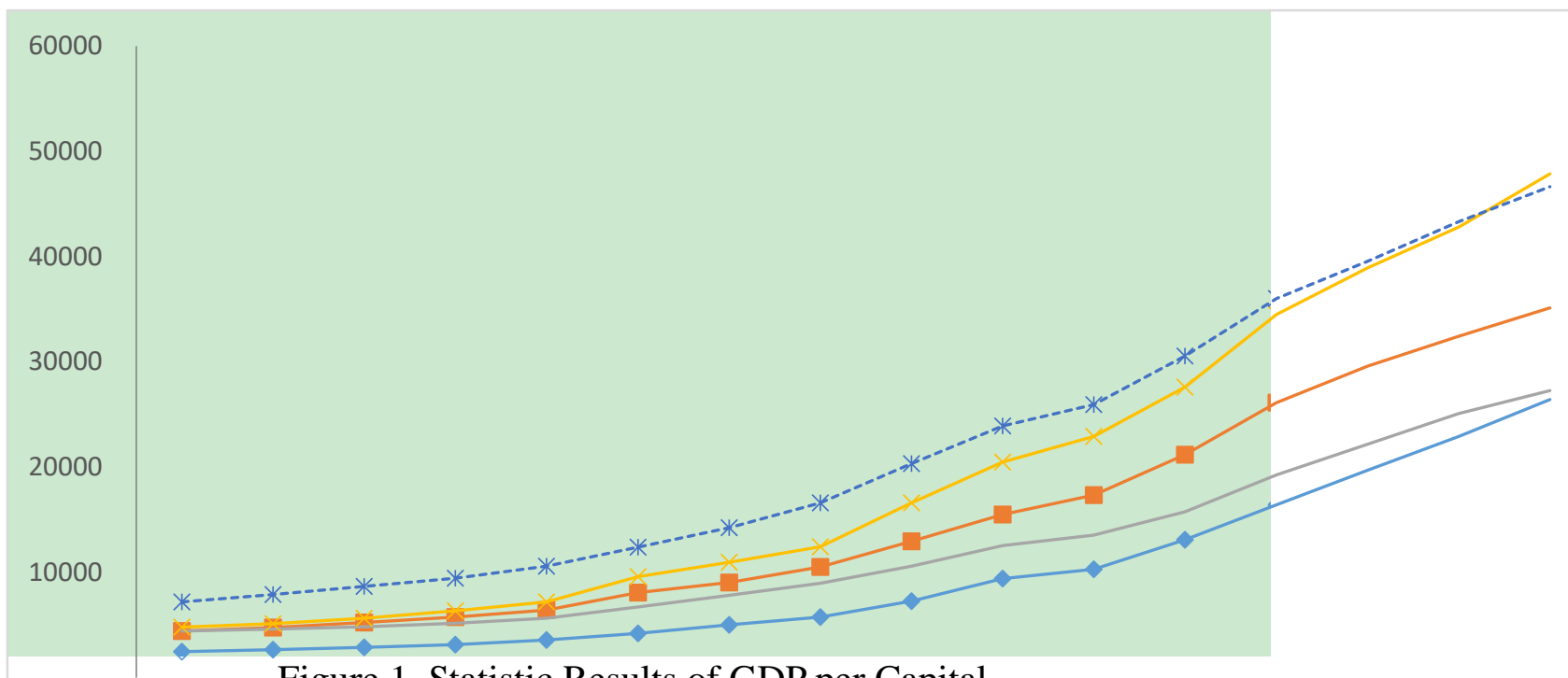

Figure 1. Statistic Results of GDP per Capital

This figure shows that the GDP per capital of the 4 provinces is lower than national level. That means the economic gowth in the 4 areas is lower than other provinces of China. The local governments of these areas need pay more attention to enhance the efficience of finance and other resources to promote economic growth and development. More importantly, the economic gowth in Chongqing City is the most fast and Guizhou province is the lowest in Southwest of China.

\subsection{Variable Stationary Test}

2.3.1 Unit root test and Cointegration test

The theory uses the ADF method to make stationary analysis on all variablequantities.

The result of the unit root test shows that the GPD time is non-reposeful time series, and it is integrated of order1. It necessary to apply the co integration analysis on the method of Johansen cointegration test. The Table 1 reports the result of Johansen cointegration test.

Table 1 Result of Johansen Cointegration Test

\begin{tabular}{lllllll}
\hline & \multicolumn{2}{c}{ No cointegration } & \multicolumn{2}{c}{ At most 1 } & \multicolumn{2}{c}{ At most 2 } \\
\hline \multirow{3}{*}{ ALL } & J-Statistic & P-Value & J-Statistic & P-Value & J-Statistic & P-Value \\
Guizhou & 109.2 & $0.0000^{* * *}$ & 25.50 & $0.0013^{* * *}$ & 12.33 & 0.1372 \\
Sichuan & 119.9361 & $0.0000^{* * *}$ & 60.7908 & $0.0019^{* * *}$ & 32.0250 & $0.0273^{* *}$ \\
Yunnan & 106.8611 & $0.0000^{* * *}$ & 47.2448 & $0.0570^{*}$ & 17.4088 & 0.6098 \\
Chongqing & 124.0038 & $0.0000^{* * *}$ & 46.5162 & $0.0664^{*}$ & 23.4103 & 0.2265 \\
\hline
\end{tabular}

$*(* *)$ denotes rejection of the hypothesis at the $5 \%(1 \%)$ level.

On the base of outcomes of AIC、SC、LR、HQ, this paper affirm the optimal lag order of the VAR model is 2 (no constraint VAR), and the optimal lag order of the VAR model is 1 . And the table 1 also reports that there is a long-term stability of the relationship between the time series of the data of 4 provinces and the overall.

2.3.2 Granger Causality Test

Table 2 reports the results of granger test. 
Table 2. Results of Granger Causality test

\begin{tabular}{|l|l|l}
\hline Null Hypothesis & F-Statistic & Prob. \\
\hline FIR does not Granger Cause EDUCA & 0.55329 & 0.5934 \\
\hline EDUCA does not Granger Cause FIR & 2.66994 & 0.1229 \\
\hline GDP does not Granger Cause EDUCA & 0.77632 & 0.4886 \\
\hline EDUCA does not Granger Cause GDP & 3.64886 & $0.0691^{*}$ \\
\hline INVEST does not Granger Cause EDUCA & 0.12731 & 0.882 \\
\hline EDUCA does not Granger Cause INVEST & 6.64672 & 0.0169 \\
\hline MI does not Granger Cause EDUCA & 1.40858 & 0.2936 \\
\hline EDUCA does not Granger Cause MI & 3.42714 & $0.0782 *$ \\
\hline GDP does not Granger Cause FIR & 4.06566 & 0.0552 \\
\hline FIR does not Granger Cause GDP & 2.58201 & 0.1299 \\
\hline INVEST does not Granger Cause FIR & 2.28637 & 0.1574 \\
\hline FIR does not Granger Cause INVEST & 0.79227 & 0.482 \\
\hline MI does not Granger Cause FIR & 0.94724 & 0.4233 \\
\hline FIR does not Granger Cause MI & 4.21269 & 0.0511 \\
\hline INVEST does not Granger Cause GDP & 5.61453 & $0.0261 * *$ \\
\hline GDP does not Granger Cause INVEST & 0.3377 & 0.7221 \\
\hline MI does not Granger Cause GDP & 2.80135 & $0.0473 * *$ \\
\hline GDP does not Granger Cause MI & 0.47116 & 0.6388 \\
\hline MI does not Granger Cause INVEST & 3.99208 & 0.0574 \\
\hline INVEST does not Granger Cause MI & 0.26053 & 0.7763 \\
\hline TRADE does not Granger Cause EDUCA & 0.52365 & 0.6094 \\
\hline EDUCA does not Granger Cause TRADE & 1.84895 & 0.2125 \\
\hline TRADE does not Granger Cause FIR & 5.02736 & 0.0342 \\
\hline FIR does not Granger Cause TRADE & 4.09374 & 0.0544 \\
\hline TRADE does not Granger Cause GDP & 10.8221 & $0.004^{* *}$ \\
\hline GDP does not Granger Cause TRADE & 6.72144 & 0.0164 \\
\hline TRADE does not Granger Cause MI & 1.41739 & 0.2917 \\
\hline MI does not Granger Cause TRADE & 1.14812 & 0.3597 \\
\hline TRADE does not Granger Cause INVEST & 0.52484 & 0.6087 \\
\hline INVEST does not Granger Cause TRADE & 15.035 & $0.0014 * *$ \\
\hline
\end{tabular}

The results shows that all dependent variable is the Granger reason of GDP, and not vice versa. And control variable is the Granger reason of some dependent variables, so the control variables will effectively reduce the endogenous risk of the model.

\section{EMPIRICAL STUDY ON THE EFFECT OF GOVERNMENT PATICIPATION}

\subsection{Hausman Test}

The purpose of hausman test is terrify the random effect model or fixed effect model used in regression analysis. The results of test is $\operatorname{Prob}<0.001$, shows that fe-model would be better than re-model to explain the relation of all variables. The regression residuals of model can be test by unit root. The results testify there is cointegration in the time series data of 4 provinces.

\subsection{The Regression result and Analysis Based on panel-data}

3.2.1 We have choose corresponding model to analysis according to the results of hausman test. The regression results is reported in Table 3. 
Table 3 Regression Results of 4 Provinces

\begin{tabular}{ccccc}
\hline & GUIZHOU & SICHUAN & YUNNAN & CHONGQING \\
\hline \multirow{2}{*}{ intercept } & 1374.89 & -2157.378 & 1217.4 & -434.9051 \\
& $(1.7418)^{*}$ & $(1.7418)^{*}$ & $(1.7418)^{*}$ & $(1.7418)^{*}$ \\
FIR & 315.902 & 2622.43 & 107.799 & 654.694 \\
& $(1.4547)$ & $(4.3520)^{* * *}$ & $(0.2780)$ & $(1.9222)^{*}$ \\
MI & 532.3874 & 1102.545 & 484.8425 & 224.9347 \\
& $(10.8126)^{* * *}$ & $(9.4715)^{* * *}$ & $(3.8220)^{* * *}$ & $(2.4003)^{* *}$ \\
Trade & -147.874 & 63.06584 & 26.20816 & 13.32919 \\
& $(-2.3455)^{* *}$ & $(4.1601)^{* * *}$ & $(0.8078)$ & $(4.0808)^{* * *}$ \\
Invest & 103.2228 & 61.4549 & 73.5205 & 96.0757 \\
Adjusted - R & $(8.6178)^{* * *}$ & $(5.5842)^{* * *}$ & $(4.7718)^{* * *}$ & $(18.8426)^{* * *}$ \\
F -Statistic & & \multicolumn{2}{c}{0.9982} & \\
D - W Statistic & & \multicolumn{2}{c}{1308.796} & \\
\hline
\end{tabular}

3.2.2 Analysis about regression results

Based on panel data of 4 provinces of Southwest of China during 1999-2014, this paper empirically test the relation between financial development and economic growth on the consideration of local government participation. The regression results shows that:

(1) There is a magnificent, positive relation between independent variables and economic growth in 4 provinces of Southwest of China. And the finance development in past decades has contributed immensely to economic growth.

(2) Specifically, there is a magnificent, positive relation between the four independent variables with dependent variable (GDP) in Chongqing. And it will make greater contributions to economic growth in this area.

(3) The variable of Trade has a negative relation in Guizhou province, but MI and Invest has positive effects on the economic growth in the same area.

(4) There is a significant regional deference in the regression results of 4 provinces. So the promotion from finance development in Chongqing and Sichuan has more obvious, notable effect than which in Guizhou and Yunnan provinces.

\section{CONCLUSION}

The results presented in this paper provide empirical support for the idea that the government have played an important role in the finance development in the 4 provinces of Southwest of China. And which has made enormously contribution the economic growth and society development of those areas.

And we have to mention that there is regional difference in these areas of Southwest of China. Such as the economic growth in Chongqing and Sichuan province is more sensitive on the finance market that in Yunnan and Guizhou. The later maybe has much depends on tourism but not on large-scale industry. So the development level and flexibility of finance is relatively low than others.

Moreover, the econometric results on the panel of region-years observations strongly supports a positive, significant and sizeable effect of fixed assets investment (Invest). Which means the amazing progress in GDP resulted mainly from fixed assets investment. And we can get reasonable interpretation the local governments were wild about the projects of infrastructure construction, such as high-way and railway.

Based on these studies, it is believed that the government has magnificent role in the relation of finance development and economic growth. Government need choose appropriate approach to promote finance development according to different circumstance and conditions. And local government need to transfer their focus of participation, not only on finance scale, but also on efficiency of financial system. The correct position of government will facilitate more the 
development of finance and economic growth in long run.

\section{Acknowledgements}

National Social Science Fund of China(14XJL004), Humanities and Social Science Project of Chongqing Municipal Education Commission(14SKG009).

\section{REFERENCES}

[1] Arturo Galindo, Fabio Schiantarelli, Andrew Weiss. Does financial liberalization improve the allocation of investment? Micro-evidence from developing countries. Journal of Development Economics, 83 (2007) 562 - 587.

[2]Asli Demirguc-Kunt, Erik Feyen, and Ross Levine. Optimal Financial Structures and Development: The evolving importance of banks and markets. The world research paper. June 3, 2011.

[3]Joseph E. Stiglitz, Jaime Jaramillo-Vallejo, and Yung Chal Park. The role of the state in financial markets. World Bank Research Observer, Annual Conference on Development Economics Supplement (1993):19-61.

[4]Levine R, Zervos S. Stock Markets, Banks, and Economic Growth. American Economic Review. 1998, 88(88): 537-558.

[5]Mckinnon R I. Money and capital in economic development. American Political Science Association. 1973.

[6]Pan Linwei, Wu Yaling, Empirical Study on the Relation of Differentiation Policy of Finance Development and Economic Growth: Consideration of Government Participation. SHANGHAI FINANCE, 2016(03):3-8.

[7]Shaw E S. Financial deepening in economic development. Oxford University Press, 1973.

[8]Yu Xuyou, Research on Regional Financial Development of Central China-under the Perspective of Local Government Behavior, On Economic Problems, 2011(07):109-112.

[9]Zhang Jing, Shen Kunrong, Development and the Shift of China’s Economic Growth Mode-An Empirical Study Based on Fiscal Decentralization, NANKAI ECONOMIC STUDIES, 2008(6):122-141. 